\title{
Н.А. Сивцева
}

Институт гуманитарных исследований АН Республики Саха, Якутск

\section{Воззрения А.Е. Кулаковского о составлении практической грамматики якутского языка}

Аннотация: Статья представляет обзор одной из актуальных проблем развития якутского языка начала 20 -х гг. XX века - составления якутской практической грамматики. Рассмотрены оригинальные воззрения А.Е. Кулаковского по данной проблеме. В качестве основных источников использованы архивные документы по лингвистическому наследию А.Е. Кулаковского.

The article presents a survey of one of the actual problems of Yakut language development of beginning 20 years of XX century - compiling practical grammar of Yakut. The original views of A.E. Kulakovsky on compiling practical grammar are analysed. Archives documents on linguistic heritage of A.E. Kulakovsky are used as main source.

Ключевые слова: лингвистическое наследие, литературный язык, практическая грамматика.

Linguistic heritage, literary language, practical grammar.

УДК: 811.512.157'36.

Контактная информаџия: Якутск, ул. Петровского, 1. ИГИ АН РС(Я), Центр изучения творческого наследия А.Е. Кулаковского. Тел. (22) 366448. E-mail: sivna@mail.ru.

В исследовании лингвистического наследия А.Е. Кулаковского, поэта, ученого, мыслителя, общественного деятеля первой четверти XX века, до сих пор в качестве основного источника служили его статьи и материалы по якутскому языку, напечатанные в одноименном сборнике под редакцией Н.С. Григорьева [Кулаковский, 1946] и вошедшие отдельной главой в сборник научных трудов Кулаковского в 1979 г. [Кулаковский, 1979]. В настоящее время перед исследователями стоит задача привлечения дополнительного материала в виде личных писем, некоторых архивных документов, позволяющих дать возможность для наиболее системного раскрытия развития научных изысканий Кулаковского в области якутского языка.

В нашей статье дается обзор основных положений Кулаковского по составлению практической грамматики якутского языка.

Значение грамматики, как науки о грамматическом строе языка, заключается в выведении грамматических правил из материалов языка, вскрытии связей и отношений между правилами, придавая им при этом более систематический вид. Знание этих правил приносит большую практическую пользу. Грамматика влияет в разработке норм литературного языка. С помощью грамматики можно сделать обоснованный выбор из существующих в языке вариантов и параллельных форм и установить единые правила общего языка народа [Грамматика, 1982, с. 31-32].

Составление якутской грамматики было заветной мечтой Кулаковского. При этом он имел свои оригинальные воззрения относительно данной проблемы.

В 1925 г., работая заместителем председателя научно-исследовательского общества «Саха кэскилэ», Кулаковский был назначен заведующим секции языко- 
ведения и лингвистики. В Национальном архиве РС (Я) сохранились документы, свидетельствующие об участии Кулаковского в деятельности «Саха кэскилэ». В частности, в первом протоколе от 31 марта 1925 г. заседания данного общества сообщается о поручении Кулаковскому «представить свои соображения в области языковедения и лингвистики» [НА РС (Я), ф. 60, л. 3]. В этом отношении интересен «План работы по якутскому языку» Кулаковского, датированный от 15 апреля 1925 г., который хранится в фонде Национального архива РС (Я) в документах научно-исследовательского общества «Саха кэскилэ» [НА РС (Я), ф. 386, л. 1]. Этот документ впервые был введен в научный оборот в кандидатской диссертации Л.Р. Кулаковской «Научная биография А.Е. Кулаковского: личность поэта и его время» [Кулаковская, 2003].

Структура документа состоит из небольшого вступления и шести отдельных пунктов, определяющих направление предстоящих работ в этой области. К первому пункту своего плана Кулаковский относит «составление популярной практической грамматики для школ». «Надо заметить, - пишет он, - что грамматика Хитрова слишком древняя и потому устарелая, а также не имеет циркулирующих экземпляров, грамматика Ястремского написана специально для лингвистических изысканий» [НА РС (Я), ф. 386, л. 1].

К 20-м гг. ХХ в. уже существовали якутские грамматики, составленные представителями духовенства (грамматика Д. Хитрова), науки (грамматика О.Н. Бетлингка), политической ссылки (грамматика С.В. Ястремского). Однако эти труды не устраивали Кулаковского по следующим причинам. Несмотря на существование вышеперечисленных грамматик якутского языка, ни одна из них не могла применяться в качестве удобного учебного пособия. По мнению Кулаковского, грамматика Д. Хитрова в этом отношении давно устарела и по качеству содержания не отвечала требованиям современного учебника. А грамматики якутского языка, написанные О.Н. Бетлингком, С.В. Ястремским, по своим целям и задачам также были мало пригодны в преподавательской и учебной деятельности в школе.

Таким образом, Кулаковский впервые в области якутского языкознания поставил проблему соответствия научной и практической грамматики якутского языка, что актуальна и в современных условиях. Действительно, в первой четверти XX века в качественном и количественном отношении наблюдалась диспропорция между научными и практическими грамматиками якутского языка в пользу первых.

Кулаковский, как педагог, общественный деятель, истинный знаток своего родного языка, понимая всю злободневность данной проблемы, выявляет в качестве первоочередной задачи составление якутской практической грамматики в виде учебного пособия еще и по тому обстоятельству, что изучение родного языка в школах является реальным условием, непосредственно способствующим развитию литературного языка. В этой связи практическую грамматику, наравне с другими учебными пособиями, можно рассматривать как наиболее эффективный нормализующий фактор, через который образовались, закреплялись и распространялись бы нормы литературного языка [Слепцов, 1990, с. 74].

О необходимости создания практической учебной грамматики якутского языка Кулаковский писал еще в 1913 г. в своем письме к И.С. Говорову: «Грамматика якутского языка Сергея Ястремского... слишком научная вещь, чтобы получить распространение среди якутов. Даже я прочитал ее (более 300 стр. большого формата) с великим трудом. Дело в том, что она вся испещерена выдержками из шести тюркских языков и 3 европейских языков. Якутская грамматика Бетлингка писана на немецком языке» [Кулаковский, 1989, с. 112]. Из содержания данного письма видно, что для Кулаковского в качестве идеального образца практической грамматики выступала «Грамматика алтайского языка», составленная членами Алтайской миссии Н.И. Ильминским, В.И. Вербицким и архимандритом Макари- 
ем. Действительно, исследователи отмечают образцовый характер данной грамматики в разработке грамматического строя тюркских языков [Кулаковский, 1989, c. 112].

Знание грамматических правил вырабатывает более сознательное отношение к языковому употреблению, учит правильно выбирать языковые средства, умело пользоваться языком и совершенствовать свою речевую деятельность. Знание грамматических правил особенно необходимо при изучении неродного языка [Грамматика, 1982, с. 31-32].

Кулаковский также подчеркивал важность приобретения новых знаний на основе родного языка, глубокому основательному изучению которого способствовала бы практическая грамматика. По этому поводу он писал следующее: «...Грамматика материнского языка необходима при изучении грамматик других языков для проведения аналогии, так как всякое новое понятие приобретается именно при посредстве аналогии познанного с познаваемым. Молодой якут гораздо быстрее усвоит русский язык и русскую грамматику в том случае, когда он заранее будет подготовлен в знаниях родного языка, который и будет служить исходным пунктом дальнейшего лингвистического похода его» [Кулаковский, 1979, с. 384].

Кулаковский в своих статьях и письмах с большим беспокойством отмечал, что многие якутские интеллигенты, образованная молодежь, не зная всех красот и богатств родного языка, «считают его негодным для культурного человека» [Там же, с. 387]. В этом отношении якутская грамматика, великолепно репрезентирующая всю «замечательную конструкцию» якутского языка, наглядно и доступно демонстрирующая все богатство его грамматических форм, позволила бы заполнить пробел в знании родного языка.

В связи с вышесказанным необходимо отметить и другую причину, побудившую Кулаковского написать якутскую грамматику. Он считал, что никому не дано лучше чувствовать всю красоту и богатство языка как его носителю. По этому поводу он писал в своем письме к И.Н. Барахову: «Я недоумеваю - почему составление якутской грамматики - поручено..., хотя бы и ученому. Ведь, одного теоретического знания лингвистов недостаточно на это дело. Между прочим, мне удалось открыть правила о склонениях изменяемых частей якутского языка, вполне закономерные. Оказалось, что наш язык замечательно правилен в отношении грамматических форм, что отчасти доказывается вот чем: все склонения я поместил в двух только диаграммах и написал к ним объяснительные правила, которые не смогли открыть ни Хитров, ни Бетлингк, ни Ястремский. Удастся ли это Поппе - не знаю. Про эти открытия я сообщал Наркомпросдраву, но он не проявляет интереса, так что я даже начинаю опасаться, что он оставит их совершенно без утилизации» [НА РС (Я), ф. 181, л. 19-20].

В момент написания этого письма ученому-лингвисту Н. Поппе было поручено составление якутской грамматики практической направленности. Из вышеприведенного видно тревожное волнение Кулаковского в реализации его требований в составлении практической якутской грамматики: вероятно, он полагал, что целью очередной грамматики якутского языка, написанной ученым-лингвистом не носителем языка, будет в большей степени внимание лингвистическому аспекту и не будет достаточно учтена практическая сторона данной грамматики.

Известно, что в это время, Кулаковский уже приступил к составлению своей грамматики. Об этом свидетельствует отрывок из его письма к П.А. Ойунскому, написанный в 1925 г.: «После лечения я должен ехать в Москву доканчивать якутскую грамматику, пользуясь разными пособиями, указаниями лингвистов» [HA РC (Я), ф. 386, л. 16].

В протоколе № 6 от 6 мая 1925 г. общества «Саха кэскилэ» сообщается об официальном поручении Кулаковскому составить якутско-русский словарь и якутскую грамматику [НА РС (Я), ф. 468, л. 10]. В фонде Национального архива 
РС (Я) хранится запрос Н.Н. Грибановского, адресованный руководству «Саха кэскилэ», в котором перечисляются имеющиеся рукописи в архиве данного общества, заинтересовавшие Э.К. Пекарского для составления дополнительного тома «Словаря якутского языка» [НА РС (Я), ф. 468, л. 36]. Среди перечисленных материалов упоминаются три рукописи Кулаковского: «Наречия разных улусов и округов, архаизмы, омонимы, синонимы, провинциализмы и технические слова (760 слов.)», «Словарь неологизмов, т.е. новых (перенятых от русских) слов (всего 2400 слов)», «Материалы по составлению грамматики якутского языка».

К сожалению, эти материалы по составлению якутской грамматики причислены к списку ненайденных рукописей Кулаковского. Тем не менее, отдельные отрывки из некоторых документов и личных писем в определенной степени позволяют реконструировать основные воззрения Кулаковского о практической грамматике якутского языка.

\section{Литература}

Грамматика современного якутского литературного языка. Фонетика и морфология. М., 1982.

Кулаковская Л.Р. Научная биография А.Е. Кулаковского: личность поэта и его время: Автореф. дисс. ... канд. филол. наук. Якутск, 2003.

Кулаковский А.Е. Статьи и материалы по якутскому языку. Якутск, 1946.

Кулаковский А.Е. Научные труды. Якутск, 1979.

Кулаковский А.Е. Письма А.Е. Кулаковского: И.С. Говорову, Н.Н. Грибановскому / Подгот. к печати Л.Р. Кулаковская, И.Е. Федосеев; коммент. П.А. Слепцов // Полярная звезда. 1989. № 2.

Слепцов П.А. Якутский литературный язык: формирование и развитие общенациональных норм. Новосибирск, 1990. 